cambial activity and vessel differentiation, and his connexion with the Forestry Commission gave him opportumities to apply his knowledge to problems of afforestation.

Priestley had an exceptional knowledge of the literature and a memory for recorded detail with a capaeity. to fit together such scattered pieces to give a picture of his problem as a whole, where each detail fell into its right place and assumed its right value. He was himself often the first to admit that suggested interpretations of certain now lines of investigation had found their way into print prematurely, but even in such cases the interest aroused stimulated such vigorous work on the subject in question, to prove or disprove his theories, that botanical science had much to gain. The recorded facts upon which his theories were based were always sound.

Throughout his long service to science, perhaps his outstanding merits, which will long outlive him in the work of his students, have been the inspiration for research, the importance he placed upon true recording of facts and soundly based and courageous attempts to interpret them. In his teaching he maintained a freshness of outlook by the continual introduction of new methods and facts, which, from his great fund of knowledge, he selected to illumine aspects of subjects which students previously thought they had fully assimilated.

L. I. Scotr.

R. D. Prieston.

\section{Dr. Thomas Swinden}

The death of Dr. Thomas Swinden on October 27 at the age of only fifty-eight has deprived the steel industry of one of its ablest leaders, who during the past year had been playing an important part in the reorganization of research in iron and steel, and whose further help in that field would have been invaluable.

Dr. Swinden was born in Sheffield on August 15, 1886, and studied in the University of that city, being Mappin Medallist in 1905. During 1906-8 he held an 1851 Exhibition Scholarship, studying metallurgy at Stockholm and Uppsala. During 1909-13 he worked as a Carnegie Research Scholar, and was awarded the Carnegie Gold Medal. In 1913 he also obtained the degree of D.Met.

From 1909 Dr. Swinden was chief metallurgist to Samuel Fox and Co. of Stock bridge, and was later works manager and director, but in 1932 he took up the important post of director of research in the United Steel Companies, Ltd., of which Samuel Fox had become an associate company. In this capacity he built up a remarkable research organization, with an able staff and well-equipped laboratories. Many valuable contributions have been made from this centre, both to metallurgy proper and to the study of refractory materials.

Besides controlling and guiding the research work of a large industrial concern and directing its application in practice, Dr. Swinden interested himself from the beginning in co-operative research for the whole of the iron and steel industry, and was one of the most active members of the committees and subcommittees set up jointly by the Iron and Steel Institute and the Iron and Steel Federation. Within the last few months he had assumed the chairmanship of several of these in succession to the late Dr. W. H. Hatfield, and he was an indefatigable worker for those committees. As a member of the Council of the British Iron and Steel Research Association which has recently been formed to take control of this work, he would have had many responsibilities in this field. During the War he took a leading part in the work of the Technical Advisory Committee on Alloy Steels, and was a member of the metallurgioal mission to the United States in 1943, which imposed a considerable strain on those who took part in it.

Swinden's early papers dealt with the constitution and properties of the tungsten and molybdenum steels, and came at a time when there was very little information on such complex alloy systems. Later, he was responsible for much of the progress made in. the production and use of steels with controlled grain size, and in recent years he and his collaborators did excellent work on the relations between carbon, oxygen and nitrogen in steel, making many improvements in the methods for estimating those elements; and making a special study of the low-carbon stoels of the 'rimming' type.

Swinden was the most pleasant and courteous of colleagues. Very modest himself, he always gave full credit to his fellow-workers in his published work. His judgment on any disputed point was invariably trusted, on account of his wide practical experience and sound scientific knowledge. He was a faithful member of the Iron and Steel Institute, of which he had recently become a vice-president. He had received its Bessemer Gold Medal in 1941, as well as medals from the North East Coast Institution of Engineers and Shipbuilders and the Institution of Marine Engineers.

Always a hard worker, Dr. Swinden was found to be suffering from overstrain in the spring of this year and was compelled to take a rest. He had, however, apparently made a good recovery and had resumed much of his work, so his sudden death came as a shock. He had a happy married life, and leaves a widow and two sons to mourn his loss.

\section{H. Desch.}

\section{Dr. Paul Ostern}

Dr. Paul Ostern was killed by the Nazis in Lwow at the beginning of July 1941, during a pogrom in which several men of science, scholars, physicians and others died. Ostern is well known to biochemists all over the world: although young, he made brilliant contributions to biochemistry. Born in Zloczow in 1902, he studied medicine in Lwow, and joined my staff in Iy27. Ostern was especially gifted for chemical work. Though he received no special chemical training, except in my biochemical laboratory, he was able to cope with the most difficult chemical investigations. It was he who succeeded in obtaining on a large scale not only inosinic acid from muscle but also adenylic acid: during the nineteen-thirties every laboratory which was using adenylic acid for research purposes acquired it, directly or indirectly, from the Laokoon factory in Lwow, where Ostern was collaborating, and where the preparation of adenylic acid from fresh meat was under his supervision. Only in 1937 this changed, when Ostern made his brilliant discovery of enzymatic synthesis of adenylic acid from adenosin and phosphate, the method now generally employed for the production of adenylic acid-also for therapeutic purposes.

After his first research work concerning the formation of ammonia in the heart and the transformations of adenylic acid in this tissue, Osterm spent some time abroad, where his work with Krebs in Freiburg 
was interrupted by the Nazi seizure of power and Krebs leaving that country; with Verzar in Basel, and then with Krebs again, in Cambridge. In Lwow he participated in the team work, with myself and Dr. T. Mann, now in Cambridge, which led to the discovery of direct enzymatic transfer of the phosphate group from phosphoglyceric to adenylic acid, with the formation of adenosintriphosphoric acid, and to the chart of the linkage of chemieal transformation in glycogenolysis, as now generally accepted. With T. Baranowski and J. Reis (now in the British Eighth Army), Ostern discovered (1935) the direct transfer of phosphate from adenosintriphosphoric acid to creatine, and the role of the phosphocreatine-creatine system as an alternating acceptor and donor of phosphate was disclosed; in 1936 he discovered that Harden-Young fructosediphosphate is formed from the monoesters and adenosintriphosphoric acid, and this very important link in glycogenolysis and glycolysis, the inhibition of which by oxidizing agents, as recently found by Engelhardt, is the essential factor of the Pasteur effect, was discovered by Ostern and his associates. His last important discovery was made, with $\mathrm{E}$. Holmes and D. Herbert, in 1939, during a short stay in Cambridge-that glucose is formed in the liver by way of phosphorolysis of glycogen and subsequent hydrolysis of the phosphoric ester. The formation of glycogen from the Cori ester by liver enzymes was then published by these workers, simultaneously with the St. Louis group.

In 1940 Ostern was appointed professor of organic chemistry in the Medical School in Lwow. Unfortunately, he did not leave the city when the Germans approached. His many friends abroad will deeply regret the untimely death of this outstanding scientific worker. J. K. PARNAS.

\section{Prof. Forsyth James Wilson}

Prof. F. J. WiLson, Freeland professor of chemistry in the Royal Technical College, Glasgow, died suddenly on October 18. For the long period of thirty-eight years he had been associated with the College which he served faithfully and well ; his first appointment was that of chief assistant to Prof. G. G. Henderson. During the period 1914-19 he served in the Army, ultimately as chemical adviser to the Eleventh Army Corps. On more than one occasion he was mentioned in dispatches.

In 1919 Wilson returned to the College to fill the chair of inorganic and analytical chemistry. On the transfer of Prof. I. M. Heilbron to the University of Liverpool, he succeeded, at his own request, to the ohair of organic chemistry, and held that until the death of Prof. R. M. Caven, when the two chairs were amalgamated in the Freeland Chair. This is good evidence of his breadth of knowledge of the subject.

Born at Moffat in 1880 , Dr. Wilson received his earlier training at the University of Edinburgh, from which he passed after a distinguished record to Leipzig, being associated there with Hantsch and Stobbe. On returning to Great Britain he joined Prof. A. G. Green at Leeds in research on dyestuffs.

In Glasgow, he took a lively interest in all the local sections of the various chemical societies and at different intervals acted as chairman. He was meticulous in his attendance at meetings, and his general bearing in discussion was always courteous. In due course he served on the councils of the
Chemical Society and the Royal Institute of Chemistry, and held office for more than one period in each case. Nearest to his heart was perhaps the British Association, and he rarely missed a meeting of the Chemistry Section.

In the limited time available from heavy official and teaching duties, Wilson was actively engaged on research in organic chemistry, collaborating with many colleagues, among them Stobbe, Boon, Heilbron, and more recently with members of the present staff of the College, Sutherland, Hopper, Crawford, McLean, and others. His research work was mainly devoted to a study of stereoisomerism with special reference to derivatives of semicarbazide and thiosemicarbazide, and to the resolution of optically active compounds derived therefrom. Latterly, he developed a special interest in certain aspects of chemotherapy, and in this connexion was associated with Imperial Chemical Industries Ltd. He was a frequent contributor to the Journal of the Chemical Society. With Prof. Heilbron he published a very useful little book on "Chemical Theory and Calculations"; although now out of print, it earned welldeserved popularity among a wide circle of students some twenty years ago.

Wilson's work in and for the Royal Technical College, Glasgow, met with unqualified approval and success, and his influence upon his students as well as his personal relations with them were admirable. Many of them holding important positions throughout the world will recall with pleasure his warm personal interest in their well-being, both during and after college days. Of shy and retiring disposition, he was a man of considerable grace and charm, highly respected and esteemed by his colleagues, no less than by his students. W. M. Cimmarng.

\section{Dr. Henry J. S. Sand}

Dr. Henry J. S. SAND died, after a short illness, at Nottingham on October 18. He will be remembered as an electrochemist of international repute, and he had also published outstanding original work in other branches of chemistry.

Dr. Sand was born in Dundee on December 7, 1873. He received his early education at the High School, Dundee, and later at the Realgymnasium in Dresden. It was during these early years in Germany that the foundations were laid of his excellent knowledge of the German language. For a short time he studied under Hempel at the Dresden Polytechnic, and then continued his university career at Zurich, where his inaugural dissertation was published in 1898. Here he worked under Bamberger, studying organic chemistry, and was awarded the degree of Ph.D. Upon his return to England, Dr. Sand worked with Ramsay at University College, London, for a short period and then, as a holder of a Bowen Research Scholarship at the University of Birmingham during 1899-1901, commenced the studies in electrochemistry for which he is so well known.

In 1901 Dr. Sand took up the post of lecturer and demonstrator under Prof. Kipping at University College, Nottingham, and continued his researches. He was awarded the degree of D.Sc. at Birmingham in 1905. In 1914 he moved to London and held the post of senior lecturer in chemistry at the Sir John Cass Technical Institute, London, until 1921, after which date until he retired in 1938 he was head of the Department of Inorganic and Physical Chemistry. 